\title{
Reference Equation
}

National Cancer Institute

\section{Source}

National Cancer Institute. Reference Equation. NCI Thesaurus. Code C154716.

A calculation based upon a set of normalized data or values that are derived from a specified population. 